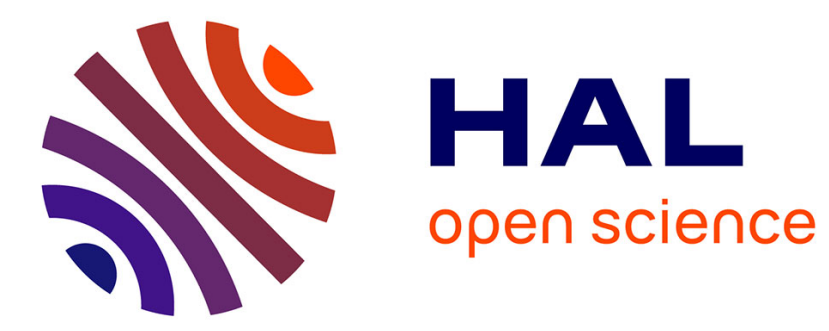

\title{
Information systems for sustainable management of groundwater extraction in France and Australia
}

John Sharples, Elisabetta Carrara, Lindsay Preece, Laurence Chery, Benjamin Lopez, Jean-Daniel Rinaudo

\section{- To cite this version:}

John Sharples, Elisabetta Carrara, Lindsay Preece, Laurence Chery, Benjamin Lopez, et al.. Information systems for sustainable management of groundwater extraction in France and Australia. Sustainable groundwater management: a comparative analysis of French and Australian policies and implications to other countries, pp.163-190, 2020, 10.1007/978-3-030-32766-8_9 . hal-02532213

\section{HAL Id: hal-02532213 https://hal.science/hal-02532213}

Submitted on 4 Apr 2020

HAL is a multi-disciplinary open access archive for the deposit and dissemination of scientific research documents, whether they are published or not. The documents may come from teaching and research institutions in France or abroad, or from public or private research centers.
L'archive ouverte pluridisciplinaire HAL, est destinée au dépôt et à la diffusion de documents scientifiques de niveau recherche, publiés ou non, émanant des établissements d'enseignement et de recherche français ou étrangers, des laboratoires publics ou privés. 


\title{
Chapter 9. Information systems for sustainable management of groundwater extraction in France and Australia
}

\author{
J. Sharples ${ }^{1}$, E. Carrara ${ }^{1}$, L. Preece ${ }^{2}$, L. Chery ${ }^{3}$, B. Lopez ${ }^{3}$, J.-D \\ Rinaudo 4
}

1. Bureau of Meteorology, Melbourne, Victoria, Australia

2. Department of Water and Environmental Regulation, Perth, Western Australia, Australia

3. BRGM (French Geological Survey), Orléans, France. France

4. Brgm (French Geological Survey), Montpellier University, Montpellier,

Corresponding author: J.Sharples@bom.gov.au

\begin{abstract}
Sustainable groundwater management relies on data to establish resource conditions and measure the effects of management intervention. As groundwater management grows in size and complexity so does the data needed to inform it, and the systems needed to manage this data. This chapter presents a discussion of groundwater information systems, their history, and examples of their application in France and Australia, including how these systems are used to inform and improve groundwater management. Examples are presented demonstrating the application of information systems in a range of agencies and legislative settings. These examples include systems used for local management, national data standardization, online data sharing, and environmental impact assessments. Finally, lessons learned and future developments are presented. This includes a comparison of the similarities and differences in the history and current state of groundwater management system development in each country.
\end{abstract}

\section{Keywords}

Groundwater Information Systems, data, groundwater level 


\section{Introduction}

Monitoring is an essential element of any effort to integrate groundwater science with water-management decisions (Holliday et al., 2007; Vaessen \& Brentführer, 2014). Monitoring is especially important where anthropogenic impacts, such as pumping or pollution discharge, create stresses in an aquifer. Pumping without monitoring extraction or the state of the aquifer is like a business continually withdrawing money from a bank account without any bookkeeping system (Nelson, R, 2011). Hence, for a groundwater system to be managed effectively, the resource must be monitored to account for the "credits" and "debits". For groundwater resources this bookkeeping system is a Groundwater Information System (GWIS). These systems have become invaluable for groundwater resource management.

The focus of this book is quantitative management. As such, this chapter will only cover issues related to groundwater quantity monitoring, leaving aside the extremely important issue of quality (chemical) monitoring. Quantity monitoring focuses on the flows of water entering and leaving aquifers, on variation of water levels, and storage within the aquifers. Quantity monitoring systems are set up to provide technical and administrative information on (1) extraction points (wells and boreholes databases); (2) associated actual water extraction (pumping databases); and (3) water resources quantitative states, which can be assessed through water levels, e.g. water flows in springs, base flow to streams and rivers.

Other chapters have shown how quantitative groundwater data informs management decisions. In this chapter, the collection and management of that data is discussed. Monitoring systems, data management systems, and their relationship to resource management decisions, are also briefly described. Example GWIS in France and Australia are presented to highlight successes and challenges in those countries. Lastly, lessons learned and future challenges for these systems are discussed.

\section{A Framework to Analyse the Development of Groundwater Monitoring and Information sys- tems}

Groundwater Information Systems (GWIS) are the systems used to collect, store, and publish data relating to groundwater. These systems are ubiquitous with good management practices and have been developed by nations around the world to monitor groundwater resources (Lee and Kwon, 2016; Klug and Kmoch, 2014; Brodaric et al, 2009). Although many variations exist, reflecting local hydrogeology and management objectives, these systems are typically comprised of several distinct components; a monitoring network, a data store, and a data interpretation and 
publication system (Table 9. 1).

Table 9. 1: Groundwater Information System components. Adapted from UNECE Task Force on Groundwater Monitoring \& Assessment (2000) and Tuinhof et al. (2006).

\begin{tabular}{|c|c|}
\hline $\begin{array}{l}\text { Monitoring } \\
\text { network }\end{array}$ & $\begin{array}{l}\text { - Sites: bores, piezometers, wells, springs } \\
\text { - Monitoring equipment: data loggers, manual readings, } \\
\text { telemetry, flow meters } \\
\text { - Data collection procedures: sampling, handling, labor- } \\
\text { atory tests }\end{array}$ \\
\hline Data store & $\begin{array}{l}\text { - } \quad \text { Data entry process } \\
\text { - Quality checking and control } \\
\text { - } \quad \text { Relational database } \\
\text { - Value add and contextual data }\end{array}$ \\
\hline $\begin{array}{l}\text { Publication } \\
\text { and interpreta- } \\
\text { tion }\end{array}$ & $\begin{array}{ll}\text { - } & \text { GIS } \\
\text { - } & \text { Reports } \\
\text { - } & \text { Assessments } \\
\text { - } & \text { Groundwater models } \\
\text { - Internet data applications } \\
\text { - }\end{array}$ \\
\hline
\end{tabular}

\subsection{Groundwater monitoring networks}

The types of sites monitored, the number of sites, the kinds of data collected, and the frequency of monitoring will depend on the hydrogeology of the groundwater system as well as the desired management outcomes. However, in most systems the majority of monitoring occurs via piezometers, bores and wells. As such, data derived during bore construction and development typically forms the basis for a GWIS (Jousma, 2008). This data includes bore and site details, lithological and hydrogeological information, and bore construction details. This data is crucial in properly understanding and interpreting monitoring data from these bores.

Ubiquitous to all groundwater monitoring are measurements of groundwater level, or pressure head, measured in a bore. These data are the principal source of information about the hydrologic stresses acting on aquifers (Taylor and Alley, 2001; Tuinhof, 2006). Groundwater levels are used extensively to understand the hydraulic setting, being the primary way of estimating groundwater flow direction 
and magnitude. The value of groundwater level data increases with the length of ongoing monitoring. As groundwater typically responds slowly to changing stresses, long-term records of groundwater level are invaluable for evaluating the impact of these stresses. In more developed resources, where a greater degree of management is required, long-term level data is essential to develop groundwater models and for assessing the effectiveness of current and past management interventions (Taylor and Alley, 2001). As such, monitoring changes in groundwater level should be a key component of all GWIS.

Monitoring frequency of groundwater levels is an important factor to consider when setting up GWIS. In general, aquifers require more frequent monitoring if they are: shallow or unconfined, have a high through flow or recharge rate, have a higher level of extraction, or show a strong response to climate conditions or link to aquatic and related terrestrial ecosystem features. For extensive, confined aquifers changes in groundwater level typically occur very slowly. Adequate monitoring for such systems might be achieved with seasonal or annual records of water levels. Whereas monthly, weekly or continuous monitoring may be required in shallow, unconfined aquifers. For new, unknown resources, frequent or continuous water level monitoring should be considered to identify the magnitude and frequency of aquifer fluctuations (Taylor, 2001). The frequency can be appropriately adjusted once an understanding of the groundwater system is developed.

In areas where a licence or permit is required for the extraction of groundwater, compliance monitoring may be needed. This data should be part of the GWIS and link the licence to the physical resource, including the aquifer and bores used to extract groundwater. This is often not the case as the need for licensing administration systems typically arises long after monitoring data systems have been developed. Direct extraction monitoring, by fitting a meter to groundwater pumps, is the most accurate method, but costly and often difficult to implement, as it requires the cooperation of water users. Where meters are not feasible, surrogate measures may be employed to estimate use. For example, energy consumption from pumping, or hours of pump operation. In rural areas where agriculture is the dominant groundwater use, remote sensing can be used to infer groundwater use by estimates of evaporation or crop growth and coverage (Vaessen \& Brentführer, 2014; Tuinhof, et al., 2006). These estimation methods, however, do not typically form part of the core monitoring network but are added in the data interpretation phase of the GWIS.

In the practical implementation of a monitoring program, quality assurance and quality control must be carefully implemented to ensure the validity of the collected data. For detailed discussion of data validity see, for example, Jousma, 2008. Table 9. 2 summarises the above discussion by giving broad groups of monitoring systems, and the types of management decisions they inform. 


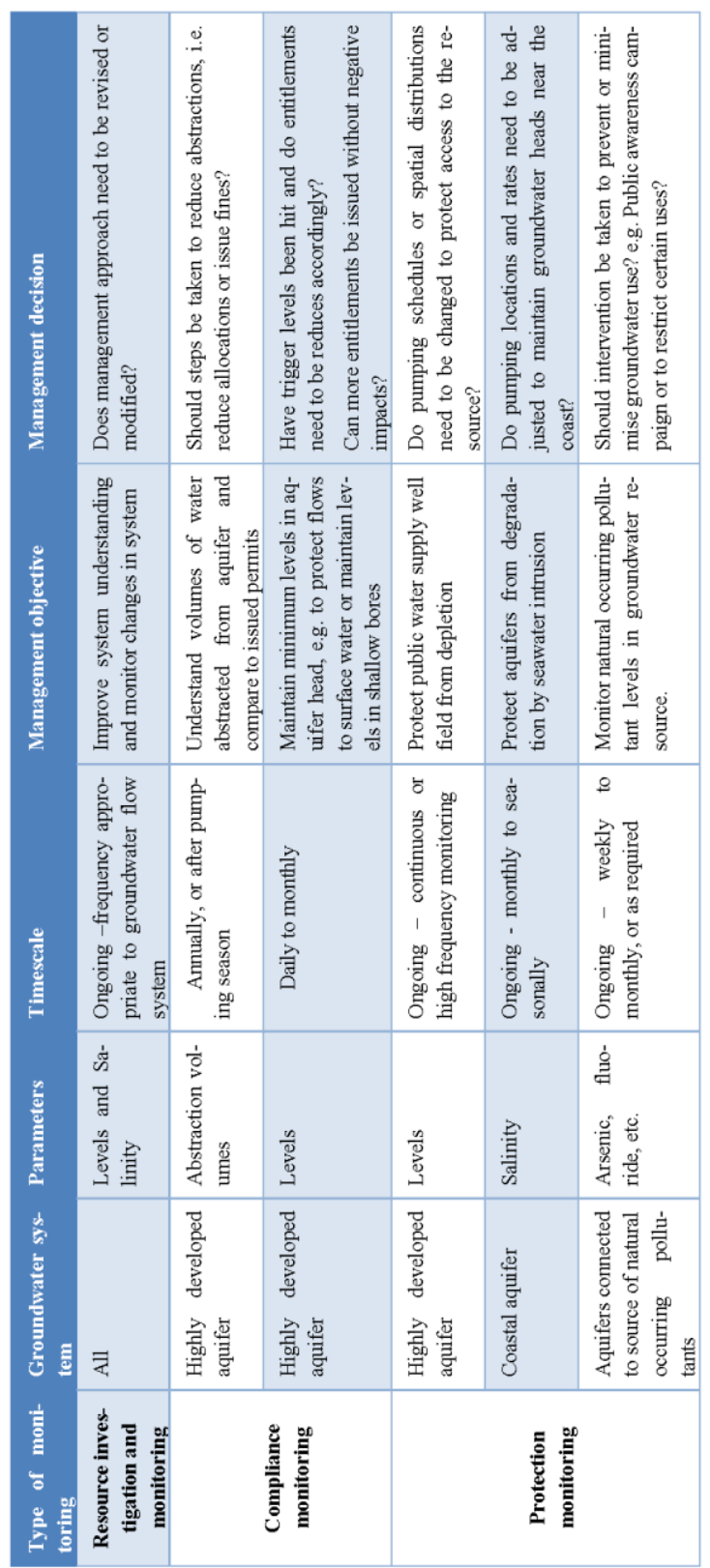


Table 9. 2: Examples of groundwater monitoring types and the management decisions they support

Once monitoring data has been collected, quality controlled and assured, it is imperative that it be systematically and securely stored for future use. Long-term records of groundwater data are invaluable in understanding, managing and forecasting resources. Ideally, this store should be a persistent relational database (Vaessen \& Brentführer, 2014; Tuinhof et al., 2006; Jousma, 2008).

There are many database options for storing groundwater data. These range from generic, open source database applications through to commercial applications specifically designed for hydrologic data (Fitch et al., 2016). Commercial groundwater databases are often packaged with tools specially designed to view, interrogate, and publish hydrologic data (Fitch et al., 2016; Jousma, 2008). The choice of database application should be considered in the context of the data custodian's ability to use the application, its suitability to the data being collected, and the costs involved in initialising and maintain the application. In general, generic database applications are highly flexible but require significant effort and knowledge to build and customise for hydrogeological data. Commercial applications typically work "off the shelf" but come with software-licensing fees and may attract further costs in maintenance and customisation.

More important than the choice of technology is the design and implementation of proper data management practices. This includes defined workflow and tools, roles and governance arrangements to ensure secure storage, ease of discovery, and access, as well as ensuring the quality and integrity of the data (WMO, 2008). The data management life cycle begins with the collection of samples and measurements in the field and extends through data handling, data entry, data validation, and publishing. Ensuring that data is accurate, trustworthy and available greatly increases the capacity to make informed management decisions. When establishing a Groundwater Information System, it is imperative that the data life cycle be considered in the design and planning phase. A significant amount of literature exists to guide the creation and review of information systems (e.g. WMO, 2008; Fitch et al., 2016; Jousma, 2008).

During development of a GWIS, it is important to consult widely. This includes engaging with a wide variety of stakeholders, such as water users, resource managers, government, interest groups, NGOs, and any other related groups. Understanding the current and future information needs of these groups will help to drive the content and structure of the information system. The success of groundwater management is dependent on communication and stakeholder investment, which are greatly affected by the availability of transparent, timely and relevant information (Global Water Partnership Technical Advisory Committee, 2000).

Publication via the internet has become the default method for distributing groundwater data in many nations. There is a proliferation of online applications for visualising, mapping, and downloading groundwater data from local catchments 
through to international coverage (e.g. waterdata.usgs.gov/nwis/gw; www.jejuwater.go.kr/; ggmn.un-igrac.org/). Typically, these applications will provide functionality to view bore locations on maps, plot water level and salinity, visualise bore hole logs and constructions details, and download data. In some cases, custom PDF reports and maps can be generated on the fly.

Many GWIS also use data management tools to expose and analyse the data. A common tool is to use a Geographical Information System (GIS) to view and analyse the data in a spatial context. This can be a highly beneficial way to view groundwater data as it can be overlain with other spatial data sets such as satellite imagery, terrain maps, and cadastre layers. Spatial data inquiry can be performed using specialised GIS software (e.g. ArcGIS, QGIS) or online services like Google Earth (Vaessen \& Brentführer, 2014). Such tools are especially useful where surface features, such as land use, impact on groundwater resources. 3D visualisations are also becoming more readily available. These are particularly valuable for communicating the physical framework of aquifers, i.e. aquifer locations, confining layers extents, faulting.

One of the most versatile tools for groundwater management is the use of numerical models to estimate current and future changes in a resource. In many regions, management decisions are driven by the outputs of a groundwater model. Models are data intensive to create, calibrate and run, requiring large volumes of input data. This always includes hydrogeological and water level information and may include water quality data. Robust data systems can aid in model development by allowing quick and reliable access to groundwater data. Furthermore, as models and studies using models are becoming more ambitious in their scope, there is an increasing push to facilitate automatic data sharing via Application Programming Interface (API), web services and data sharing standards. The European Union's INSPIRE Directive is one example of a legislative requirement to share environmental data, including groundwater, via an agreed, well defined format. Major efforts have also been invested in creating international groundwater data sharing standards, such as the Open Geospatial Consortium (OGC) standard GroundWater Markup Language 2 (GWML2). Such efforts are invaluable in facilitating more complex, integrated studies in environmental and hydrological management (Alley et al., 2013; Fitch et al., 2016).

\subsection{Challenges and difficulties}

The literature has many examples of groundwater monitoring being described as a trade-off between monitoring coverage (in terms of spatial extent, frequency and number of parameters monitored) and the cost and effort required (Bartram and Ballance, 1996; Tuinhof et al., 2006; Taylor and Alley, 2001). Given the slow movement of groundwater, monitoring can be protracted. The US Department of Energy estimates spending of US $\$ 5.5$ billion on remediating polluted groundwater between 2000 and 2006, the majority of the cost going to long term monitoring. Long term stewardship is also expected to cost around US\$100 million per year for 
70 years. The US Navy expect to make similar expenditure on contamination monitoring (Minsker, 2003). While these examples are limited to pollution remediation they serve to demonstrate the magnitude of potential costs involved in groundwater monitoring.

In some situations, a "user pays; polluter pays" approach can be taken to recover the costs of monitoring and managing groundwater. Where the water manager issues licences or permits this can be achieved through collecting fees from groundwater users. This method has been successfully instituted in some countries, for example South Africa (SA Gov, 2010). However, a scale of economy comes into play, where this method has mostly been applied where few extractors take large volumes of water. For regions like Asia, which is typified by a large number of small volume extractors, such measures may not be feasible to enforce and administer (Shah et al., 2003).

New technologies, particularly in telecommunications and Internet of Things (IoT) sensors, are driving down the cost of collecting large volumes of data. Embedded sensors can now be installed inside bores and data collected via mobile networks or low flying satellite (e.g. Haley, 2017). This technology greatly increases the amount of data that can be collected, especially in remote and hard to access areas. While this technology can drive down the cost of data collection, the tradeoff is greater robustness needed in the data management components of the GWIS. Porter, et al. (2012), states that sensor technology is ahead of the information management and data storage technology typically used in water sciences. As such, adoption of new IoT and sensing technologies will require more robust and complicated data management and storage technology. Groundwater managers planning to move new or existing monitoring networks to an IoT based technology should be aware that it is an active, and fast moving, field of research and development.

In many countries, groundwater monitoring occurs for many purposes and is performed by multiple agencies. For example, one agency might monitor groundwater for resource extraction and supply, another for pollution monitoring and remediation. As these activities are typically legislative, the resulting data is often in inconsistent formats and held is separate databases (Fitch et al., 2016; Horsburgh et al., 2009; Dahlhaus et al., 2016). Similarly, where aquifers extend across administrative boundaries, data from a single resource might be collected and held by multiple agencies. This can occur internationally or within a country, e.g. across state borders. Typically, these situations are legally complicated; each agency will be operating under differing priorities, capacities, and legislation. In these cases, wide consultation can deliver great value to the design and implementation of information systems. Data sharing arrangements can provide opportunity to share monitoring and ensure best management practices can occur across borders (Vaessen \& Brentführer, 2014; UN-ECE Task Force on Groundwater Monitoring \& Assessment, 2000). This issue has been successfully addressed using data standards and API technology. The European Union's INSPIRE program is one such example. 


\section{Groundwater Information Systems in France}

\subsection{History of groundwater data and metadata collection in France}

Monitoring of groundwater levels in France began in the middle of the nineteenth Century. The oldest known groundwater level data are from boreholes located in Albian aquifer (Paris sedimentary basin) in 1840. Overall, groundwater level data remained sparse until the end of the 1960s. The first networks for groundwater level monitoring were established in response to local needs, focusing on specific groundwater resources or on specific uses (e.g. drinking water) (Forkasiewicz et Margat, 1970).

In the 1960's and 1970's, the development of wider coverage groundwater monitoring networks was initiated by several ministries and by regional governments. This expansion occurred without real coordination between the different actors developing those networks. The first network was set-up by the French Ministry for Health, under the regulatory framework of health control of water intended for human consumption. This first national network only collected information on water from boreholes used for drinking water abstraction (raw water sampling). During the same period, the Ministry of Industry also funded the French Geological Survey to set-up a groundwater level monitoring network as part of the first "inventory of hydraulic resources". The main objective was to assess existing resources which were poorly understood, to structure data collection and banking at a national scale and to draw the first hydrogeological maps.

These first uncoordinated actions were strengthened by the 1964 Water Law, which established the Water Agencies, and required them to set up water monitoring networks covering their entire territory. Each agency developed its own network, collected data and stored it in their own database. From the late 1970's, Water Agencies also encouraged and financially supported county and regional governments to establish local groundwater monitoring networks. The objective of those local authorities was mainly to monitor the increase of nitrate pollution (particularly in agricultural lands in the north and center of France) but most also monitored water levels. From 1970 to 1985, about 20 local or regional networks were created at various hydrological or administrative scales (catchments, counties, and water bodies). At the end of the 1980's, it became clear that all these independent monitoring networks should be coordinated and harmonized to improve both the geographical coverage and the consistency of data collected.

The new Water Law of 1992 provided the impetus for this reform. By imposing the elaboration of Water Resource Development and management master plans (see chapter 4), the law triggered the strengthening of existing water resource monitoring networks. Significant funding was provided to local governments and the Water agencies during the 1990s. As a result, a series of new networks were established and the number of monitoring points increased by a factor of four or five compared 
to 1970 . The harmonization of existing networks started in 1999, after the six water agencies and the French ministry of environment signed a protocol establishing a "National Network for Groundwater Monitoring" (RNES in French). This protocol defined, amongst others, a minimum density of monitoring points, frequencies for water sampling (for quality measurement) and groundwater level measurements for each type of aquifer. A harmonized grid of sampling points was established, aggregating sites identified in each of the six French water basins. The first French national groundwater monitoring network was born.

In the early 2000 's, this national groundwater monitoring network had to evolve again to comply the European Water Framework Directive (WFD) enacted in 2000 (WFD, 2000-60-CE). According to the WFD, monitoring networks must provide data for conducting a reliable assessment of the qualitative and quantitative status of all groundwater bodies including assessment of the available groundwater resource. The WFD requires establishing two types of monitoring - surveillance and operational. Surveillance monitoring aims to supplement and validate the assessment of the status of water bodies and provide information for use in the assessment of long-term trends. Operational monitoring must be carried out for those groundwater bodies which are identified as being at risk of failing to meet the environmental objectives of WFD. Overall, the objectives of the WFD being quite similar to the former RNES, most of the former sampling sites were integrated into the WFD network which became operational on January 1st 2007.

\subsection{The National Water Information System}

The progressive integration of existing groundwater monitoring networks described above was supported by the development of a comprehensive Water Information System (WIS). The WIS (http://www.eaufrance.fr) collects, organizes and provides access to all water related data produced by 50 different organisations. The information, comprising 506 data sets, is regularly updated and published for each monitoring station, covering all catchments, regions, counties and aquifers. The system ensures data traceability (e.g. origin of the data, validation level). Data are produced, processed and stored according to standards defined by a network of institutions producing water data (http://www.sandre.eaufrance.fr/). These standards include technical specifications and code lists and describe how to exchange water data at the national scale. From an IT perspective, the Sandre guarantees interoperability of all French Water Information Systems. It ensures the creation and updating of detailed data dictionaries, the updating of common references, the development of data exchange standards (in accordance with European or international standards). The WIS comprises several modules which were progressively developed (see Table 9.3). 


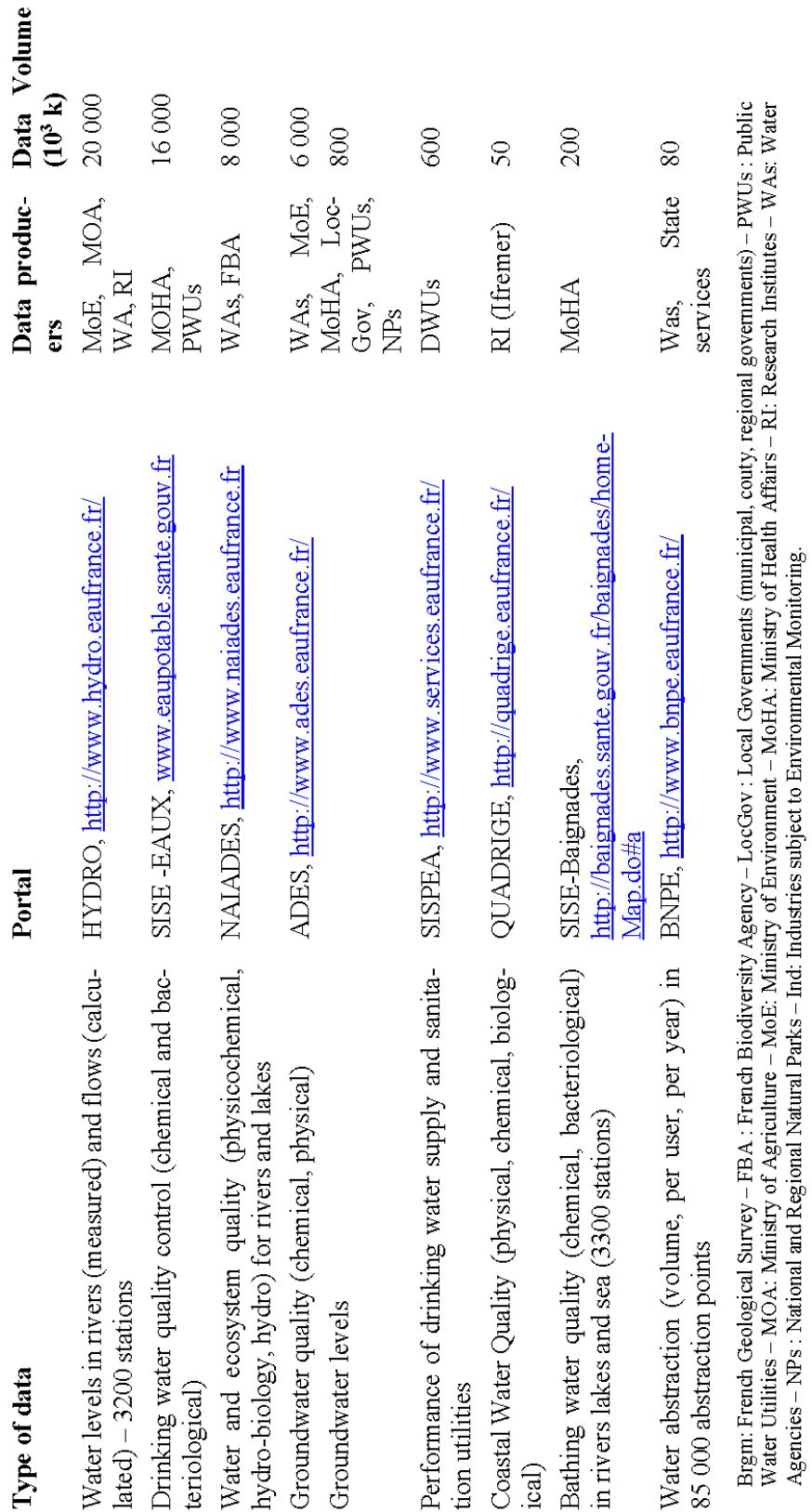

Table 9. 3: Overview of selected water data portals part of the French Water Information System 


\subsection{ADES: The national portal for Groundwater}

The development of the WIS was initiated with the creation of a groundwater portal, named ADES (Accès aux Données sur les Eaux Souterraines). ADES offers unique access to data from all groundwater networks in France (see Figure 9. 1) through a web portal (http://www.ades.eaufrance.fr). Data exchanges between participants implies certain rules defining both data content and format. The main data producers are the Ministry of Ecology, the six Water agencies, BRGM (French Geological Survey), the French Agency for Biodiversity (AFB, formally ONEMA), EDF (French Electricity company), Ifremer (Research institute for exploration of the sea), French institute for agricultural and environmental research, the French Meteorological Institute.

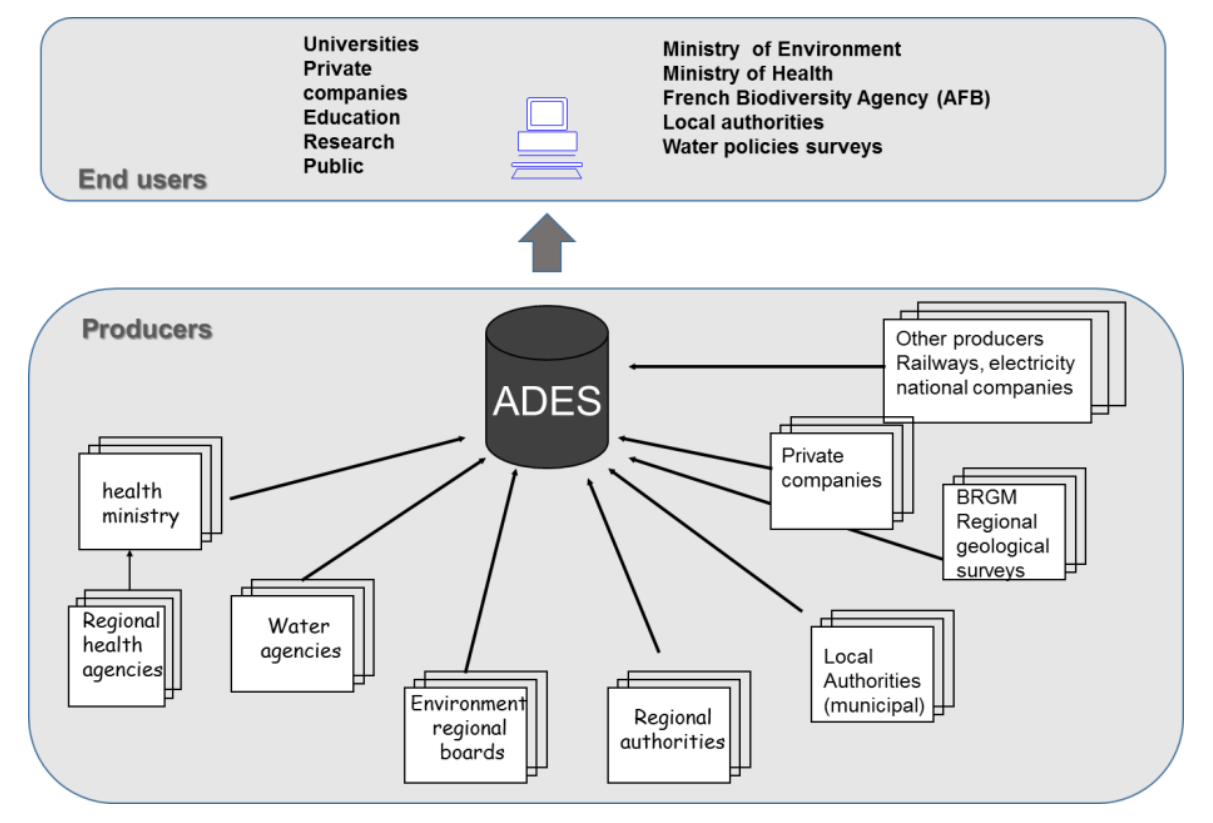

Figure 9. 1: Main data producers providing data to the Groundwater data portal (ADES)

In September 2018, the groundwater portal gives access to 15 millions groundwater levels, from 4,572 piezometers, and 76 million groundwater quality measurements, from 74,520 sampling sites. The main data users are groundwater local managers, water SMEs, drinking water producers, and environmental associations. The data is freely available to view and download. For groundwater levels, users may 
access historical data (see Figure 9. 2) but also to the results of a statistical analysis of water levels in the selected monitoring point (Figure 9.3).

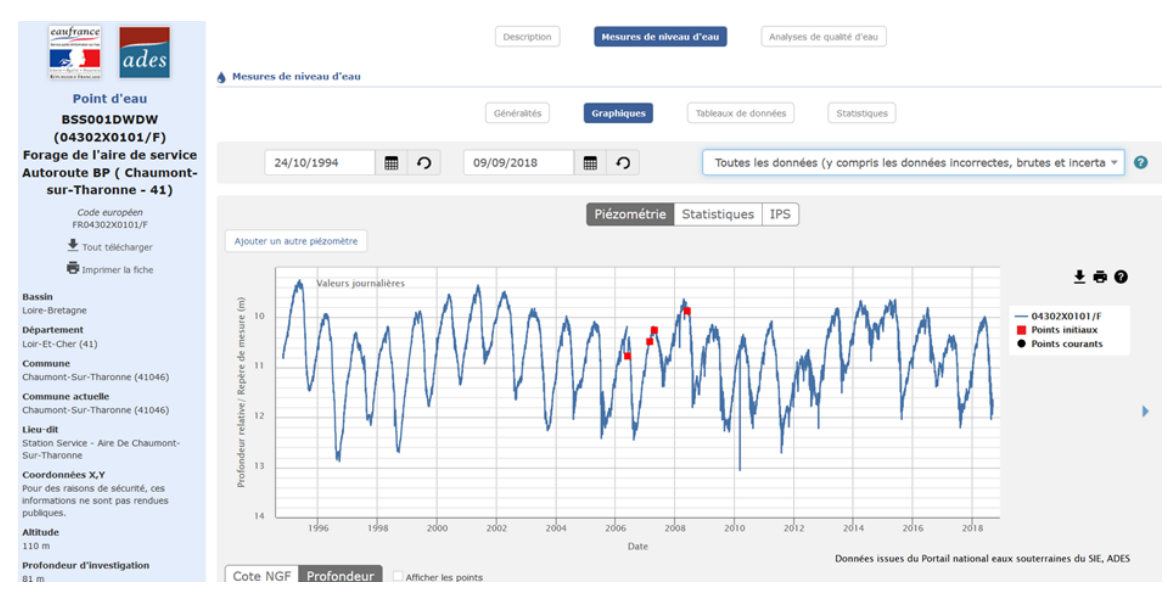

Figure 9. 2: Groundwater level evolution in a selected monitoring point (screen shot of $A D E S$ )

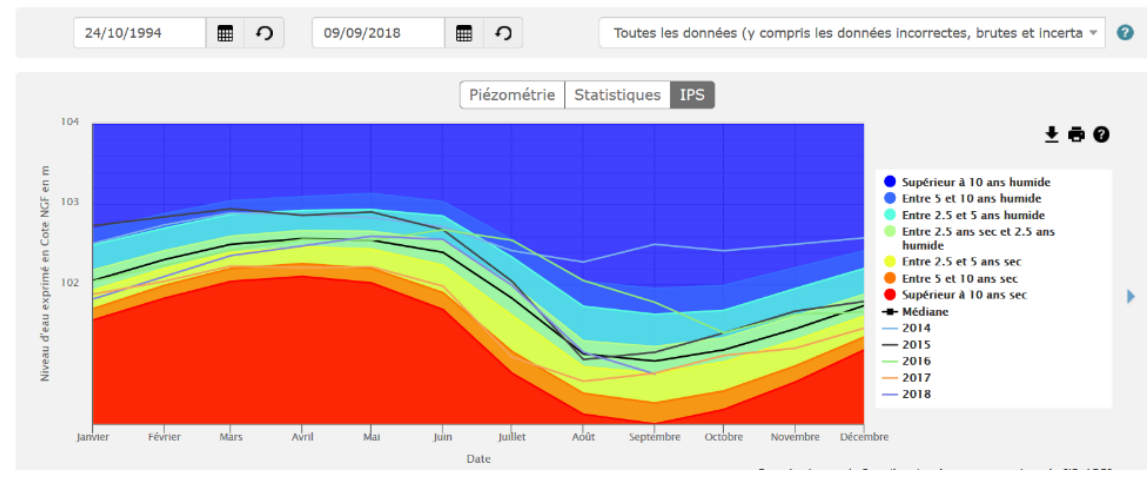

Figure 9. 3: Statistical groundwater level indicator (screen shot of ADES)

ADES also collects data from the Subsurface Database (Banque de données du Sous-Sol - BSS http://infoterre.brgm.fr/page/banque-sol-bss) which contains information related to all underground works (deeper than $10 \mathrm{~m}$ ), including all boreholes used for groundwater extraction. Established in 1958 in application of the Mining Code, the BSS contains administrative information (name of the owner, location), it identifies the aquifer exploited and it provides the description of the geological levels encountered during drilling. When available, the drilling logs have been digitized and can be accessed online on the InfoTerre Portal. The BSS makes more than 
700,000 descriptions of underground structures accompanied by a set of more than 2,000,000 digitized documents publicly available. Nearly half of the structures have a short geological section, and about $20 \%$ have an elaborate geological cross section verified by a professional.

\subsection{BNPE: the national water abstraction database}

Obtaining accurate data on groundwater abstraction is essential for resource managers. Until 2010, this information was collected by several institutions and not consolidated into a national database. The main data producers are the following:

- Water agencies. By law, all users abstracting more than $10000 \mathrm{~m} 3$ (10ML) per year, or7000 m3 (7 ML) in restriction zones, must declare the total yearly volume of water they abstracted to the water agency. This information is used to levy an abstraction tax, which is collected by each Water Agency.

- The regional Environmental Department also collects water abstraction data from all industries generating an environmental risk, and the corresponding data are stored in a database called GIDAF.

- Domestic wells are registered in a separate database.

- And Government agencies in charge of water compliance and enforcement (See chapter 23) also collect information related to actual water abstraction.

The National Water Abstraction database (BNPE in French) was set up to integrate these different sources of information. In 2018, it centralizes data from all water agencies. Further integration of other data sources is in progress. Information can be displayed for a single abstraction point or consolidated at different administrative levels (municipality, county, region) or hydrological scale (catchment, aquifer). The identity of abstractors is not disclosed, in accordance with the law.

\subsection{Other information systems on groundwater at local/regional scale}

From the 1990s, communication tools targeting the general public were developed in several French regions. Named SIGES (Systèmes d'Information pour la Gestion des Eaux Souterraines), they consist of a website which publishes information accessible to a wide public (expert, schools, and the general public). SIGES provides access to a large number of documents, maps and videos related to groundwater in a specific region. The user is offered access to different information and scientific material depending on their profile. Cross-sectional access also makes it possible to reach technical content through a map interface, a database search that links to ADES or a list of scientific literature references. The editorial information is enriched with a regular flow of information via the "News" section, and the subscription to an RSS feed. 
Since the first SIGES was developed 20 years ago in Aquitaine region, several SIGES have been set up, most often at the level of an administrative region, but also at river catchment or aquifer level (upper Rhine valley aquifer: http://sigesar.brgm.fr/-La-nappe-d-Alsace- ) or even at the River basin district level (SIGES Seine-Normandy; http://sigessn.brgm.fr/).

\section{Groundwater Information Systems in Australia}

\subsection{Historical development of groundwater information systems}

In Australia, collection and recording of groundwater information began in the late 1800's (Dahlhaus, et, al, 2016; Blake \& Cook, 2006; NSW, 2012). These early activities predate the formation of Australia and were carried out by the self-governing colonies prior to their federation into the sates of Australia. As such, they were developed independently across the country, adapting to meet local needs. This arrangement continues to the present day; groundwater monitoring and data collection primarily remains the responsibility of state and territory governments.

In Victoria early drilling and bore data were published in Diamond Drills and Water Augers, and Diamond Drills and Other Boring Machinery reports dating back to 1884 (FedUni, 2015; Dahlhaus, et al, 2016). In Western Australia, artesian bore drilling details were published in the annual reports of the Geological Survey between 1896 and 1911, and later a compiled dataset was presented at the Interstate Conferences on Artesian Water, 1912 et seq.

The tapping of the Great Artesian Basin (GAB) in New South Wales brought groundwater within the ambit of Government policy and administration (NSW, 2012). Two royal commissions in the late 1800, the Lyne Royal Commission in New South Wales (1884-1887), and Deakin Royal Commission in Victoria (18841887) laid the foundation for water legislation reforms and, in the process, collected a vast amount of water data. In Queensland, increased exploitation of the GAB lead to extensive mapping from 1894. 


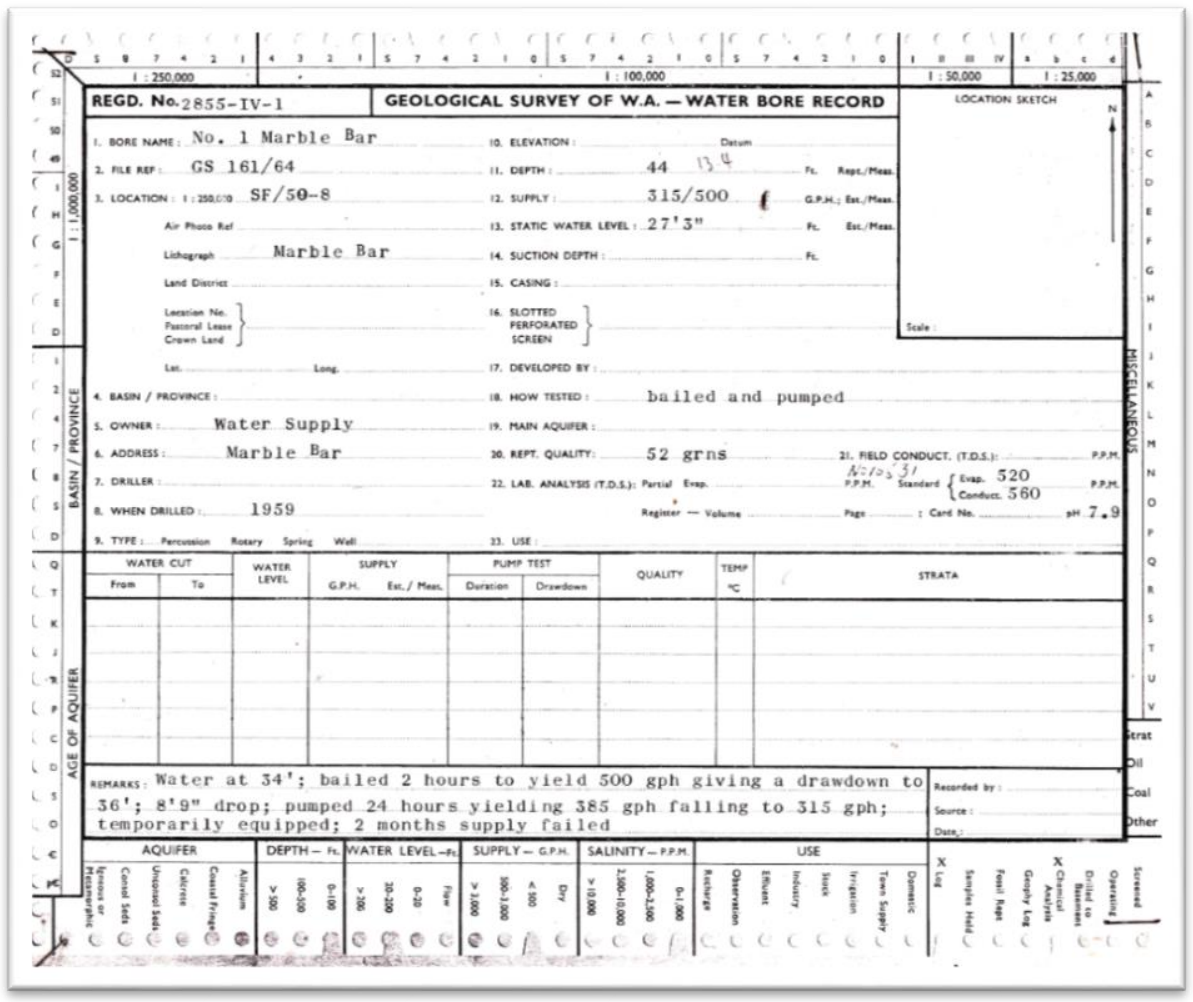

Figure 9. 4: Example of card systems for bore data in Western Australia

In these early years, data collected was primarily concerned with exploitation of groundwater resources; bore location, construction, and yield. Pressures and levels were sometimes recorded to determine potentiometric heads and map regional resources in groundwater systems (Blake \& Cook, 2006). These early data sets were recorded in hardcopy, as tabulated data, hand drawn maps, and periodically published reports. Over time some organisations developed a file system for storing bore data, typically on template cards (Figure 9. 4). This continued until the late 1960 and early 1970's when the use of computers revolutionised data.

Around this time, many state agencies established the ability to store groundwater data in digital formats. As well as storing newly collected data, historical data began to be digitised and ingested into these databases. This was the beginning of an ongoing process of storing and managing digital groundwater data (Blake \& Cook, 2006; FedUni, 2015; DoM, 1974). In some cases, only the level and salinity measurements were digitised. For example, in the 1970's the Public Works Department in Western Australia created the State Water Resource Information System (SWRIS). Although the SWRIS was primarily used for surface water data, ground- 
water level and salinity data were also recorded. However, bore data, such as construction and geology logs data remained on a card system until 1993 when the Geological Survey received funding to computerise the bore data into the AQWABase. By then a separation between levels and salinity time series databases and bore logs and construction databases started creating future difficulties in relating these two datasets. This example is typical of hydrogeological data management in many states.

From 1994 onward, a series on national water reforms began additional collection of information regarding groundwater rights and allocation, including for the environment, and trading. The 2004 National Water Initiative supported the introduction of water registers at state level. This again created separated registers to store permits, use and trading data.

While early groundwater data was collected primarily for developing groundwater resources, data was now collected for a variety of purposes, including: environmental; resource management and monitoring; resource investigation; contamination monitoring and compliance.

Significant effort went into collating data into consistent and complete datasets, however, results varied considerably for each state and territory and no standards were adopted nationally. This changed with the Water Act, 2007. The Federal government begun the task of establishing a consistent, national dataset for groundwater with a focus on promoting transparency and public data availability.

The history of water initiatives and changes to Groundwater Information System is shown below in Figure 9. 5.

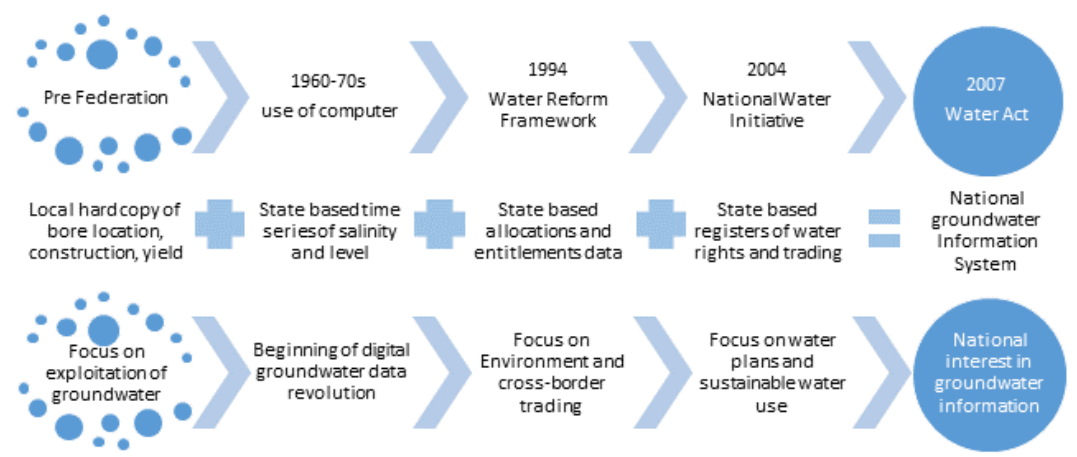

Figure 9. 5: Groundwater information systems timeline in Australia related to important events and reforms. 


\subsection{Organisation of groundwater information systems}

In Australia, collection and recording of groundwater data and metadata is carried out by a variety of organisations both public and private. The vast majority of publicly available groundwater data is collected by State and Territory governments. However, other organisations and industries also collect and record groundwater data. These include:

- Environmental Protection Agencies;

- Other state government departments;

- Water corporations - State owned corporations responsible for water supply and licensing;

- Federal agencies — such as, Geoscience Australia and CSIRO;

- Research institutions;

- Mining and energy companies.

State and Territory governments remain the primary data custodians, due to their regulatory role in bore construction, groundwater management, and environmental management. However, even within a single organisation groundwater data is often found in disparate data management systems. For example, in New South Wales and Victoria high frequency data was stored in Hydstra, a specialised time-series database used for their surface water data, and the bore and manually read data was stored in a bespoke groundwater system. Similar arrangements exist in most other states. It should be noted both Victoria and New South Wales are in the process of combining their groundwater data into single integrated systems.

There are two main causes of this division in data stores are:

- Changes in the organisaiton of government departments, and corresponding responsibilities for water data management, have led to many merges, splits, and corresponding merges and splits in GWIS.

- Ongoing developments in database technology and standards, along with increases in the volume of data collected, have led to almost constant changes in the technology. This process reflects the rapid growth in computer technology since data began to be digitised in the 1970s.

Through the Water Act, the Bureau of Meteorology (the Bureau) was given responsibilities to improve the integration, standardisation and dissemination of groundwater information across Australia. State agencies remain the primary data authority, but the Bureau is responsible for collating nationally consistent groundwater data. 


\subsection{Below are two use cases, representing a state agency and the Bureau. Case Study 1: Department of Water and Environmen- tal Regulation, Western Australia.}

The State of Western Australia relies heavily on groundwater. The major population center around Perth sources two-thirds of its water needs from groundwater (BOM, 2018). Western Australia has invested in a network of groundwater monitoring bores, gauging stations and rainfall monitoring sites. This State Reference Network has provided a comprehensive set of scientific measurements. About 10,000 groundwater sites have measurements going back to the 1970/80's, however, some measurements go back as far as the early 1900's. The valuable scientific data collected from the State Reference Network is maintained by the Department of Water and Environmental Regulation (DWER), who use the data extensively to manage Western Australia's water resources. It is a primary input into the department's groundwater and surface water models, which underpin the management of water resources (see chapter 15).

There are 2500 groundwater bores which are currently monitored on a regular basis. Of these 500 sites have groundwater loggers, with the remaining being measured manually. The manually measured bores are typically dipped four times a year, with important sites being measured monthly. One important groundwater site on the Gnangara Mound groundwater system is logged and telemetered. DWER utilises the Hydstra time series data management application for surface water and for groundwater sites. This system is highly popular in Australia for storing both groundwater and surface water data. In addition to DWER, the Hydstra information system is used by other lead water agencies in the Northern Territory, New South Wales, and Victoria. It is also used by a variety of other organisation, including the Bureau of Meteorology.

DWER has chosen to combine all groundwater, surface water and water quality testing information into this single off-the-shelf database system for several reasons. It will simplify database management and reporting functions by allowing better integration with other departmental systems running on a uniform SQL server platform and lead to better reporting capability using Business Intelligence and other tools. This approach utilises existing knowledge and expertise in the Hydstra system and extends that to groundwater and water quality information previously stored in a bespoke Oracle system. As Hydstra is specially designed for time-series data management, it provides for the growing demand for the use of loggers and telemetry in groundwater bores.

Using an off-the-shelf system also provides a clear path for system updates and upgrades because the system suppliers provides support and maintenance for the system. This reduces overall operating costs by decommissioning the legacy bespoke systems and reducing the need for DWER to maintain and develop the application. The department is a long-time user of data loggers and telemetry systems utilising both cellular network and satellite communication systems. Western Australia is predominantly a sparsely populated, desert environment. Many monitoring 
bores are located in harsh and remote environments. Hence, durable, low power equipment, which allow remote administration, is a key factor for the department when choosing equipment for its monitoring systems.

The 500 groundwater sites where loggers are currently mounted down the bore inner casing are not telemetered due to current power requirements and the lack of a suitable low power telecommunications network in the South West of Western Australia. Emerging Internet of Things (IOT) technologies may enable these bores to also be telemetered in the future.

DWER has invested in an advanced self-service water information reporting (WIR) portal to make water data available online. It provides a one-stop-shop for groundwater, surface water and water quality information for Western Australia. The portal is based on a shopping cart design and is easy to use. The data is free to access and download, the user only needs to provide a valid e-mail address to get water data.

Before WIR was introduced all water data requests were handled manually with a minimum 10 business day turnaround. WIR now provides $99.5 \%$ of all water data with an average turnaround time of 43 seconds. Consultants and Universities are big users of WIR as are mining companies, farmers and the land and property development industry. Common use cases include; assessing drainage and land fill needs for property developments; evaluating potential environmental impacts; planning and design of new roads, bridges and other transport infrastructure; as well as supporting groundwater related research and management.

This information system underpins DWERs capacity to assess information and manage groundwater resources across Western Australia. It allows groundwater managers to understand the resource; understand the ecological, social and cultural needs; measure and estimate current and future demands and trends. The system also provides primary inputs to a suite of groundwater models that underpin many management decisions.

\subsection{Case study 2: The Bureau of Meteorology}

Many organisations across Australia collect groundwater data for a range of purposes. The variety of methodologies employed in collecting, managing and transferring means that it can be difficult for other users to easily understand and interpret this data. The fractured nature of these datasets creates difficulties in producing nationally consistent information from data collected in different ways, and without reference to agreed or commonly applied standards and guidelines. The Bureau is actively working to develop water information datasets and standards, which support community understanding, comparison and sharing of water information.

The Millennium Drought (1997-2009) was a catalyst for unprecedented reforms to Australian water management, which were formalised through the National Water Initiative in 2004. As part of this reform, the Bureau was given a key role to 
improve the collection, standardisation and dissemination of water information, including groundwater, through the Water Act (2007). The Bureau is now responsible for publishing a standardised national dataset for groundwater. This is the first time such a dataset has been created and maintained for the whole of Australia.

The Water Act (2007), allowed for the creation of the Water Regulations (2008) which legislated the detailed requirements of the water information that must be given to the Bureau. The Regulations define the type of data that needs to be supplied to the Bureau and who needs to provide it, as well as the delivery frequency and format of the data. The preferred format for time series data, such as of groundwater level and salinity data, is the Water Data Transfer Format (WDTF) (Walker, 2009), an XML file format for transferring water information.

Information about bore location, construction and bore log details are also required through the Water Regulations. The preferred format is in an ESRI geodatabase using the National Groundwater Information System (NGIS) data model, which is derived from ESRI's ArcHydro for Groundwater. Each State and Territory water agency produces an NGIS database for their jurisdiction, which is integrated into a national dataset by the Bureau.

The NGIS contains data for more than 870,000 bores. Detailed information is provided about each bore, including (where available) purpose, lithology, construction and hydrostratigraphy logs. Aquifer geometry is available for some areas in 2D or 3D, including 3D hydrostratigraphy models for the Murray Basin and the Great Artesian Basin.

A major challenge for the Bureau in building a national groundwater dataset is that each State and Territory uses local terminology to describe, among other things, aquifers, aquitards, boreholes and bore pipe identification systems. These differences are problematic, particularly when examining aquifers that span multiple States and Territories. The Bureau, in collaboration with each State and Territory water agency, developed a National Aquifer Framework (NAF). Hydrogeologic data in the NGIS is standardised across the nation using the National Aquifer Framework.

Groundwater data held by the Bureau can be viewed, analysed, and downloaded through the Australian Groundwater Explorer (http://www.bom.gov.au/water/groundwater/explorer). The Explorer now contains more than 220,000 bores with water level or salinity data as provided through the Water Regulations. The Explorer provides a truly national picture of groundwater data, makes this data readily available at a national scale and puts local, State and Territory groundwater information into an Australia-wide context. 
Standing water level (WaterNSW)

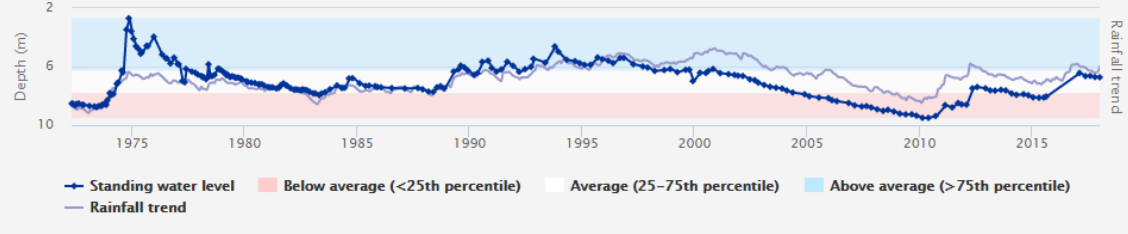

Figure 9. 6: Example of hydrograph from the Australian Groundwater Explorer

In addition to the above-mentioned data, the Bureau also collect groundwater data relating to groundwater extraction, and licences for extraction, through the Water Regulations. This data can be visualised through the interactive Australian Groundwater Insight (http://www.bom.gov.au/water/groundwater/insight). The Insight shows maps of hydrogeological information such as aquifer types, alongside information about licences, entitlements and extractions by groundwater management areas, providing background to the analysis of groundwater salinity and trends in levels presented in the application (Figure 9. 7). This significantly increases the capacity to provide a consistent analysis of groundwater resources across the nation.

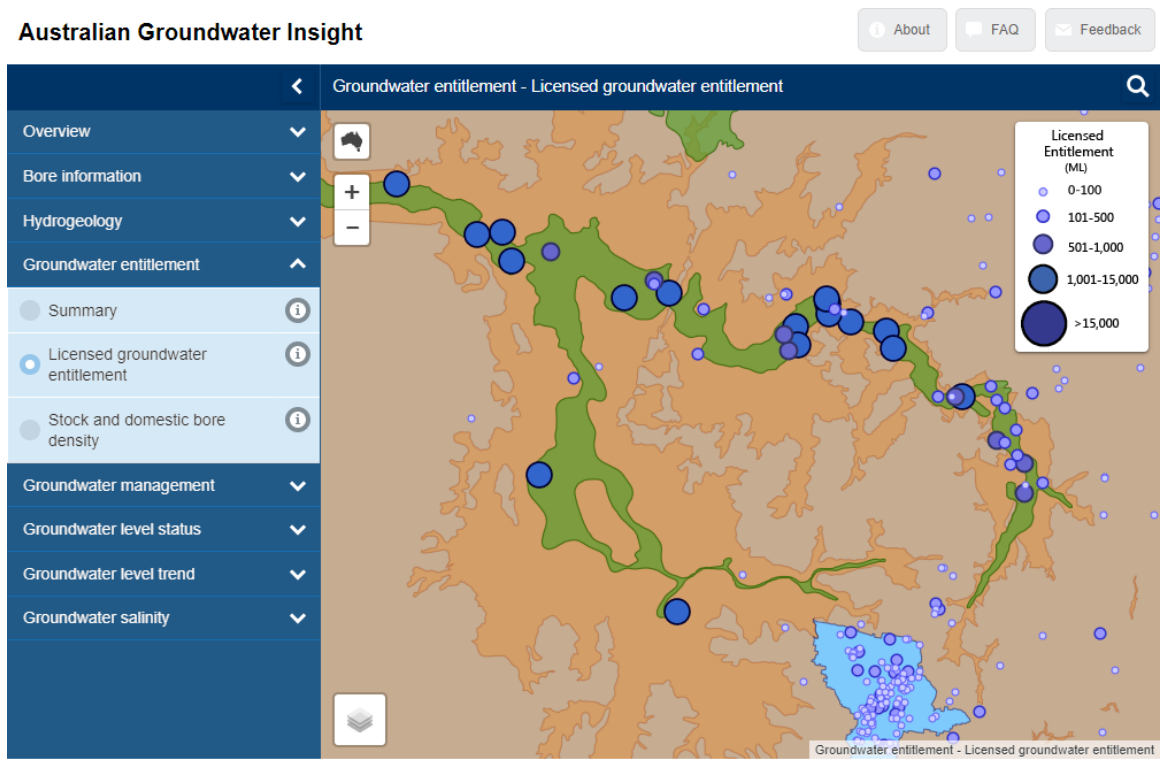

Figure 9. 7: Locations and indicative size of extraction licences and aquifers extents for the Upper Lachlan Alluvial Aquifer. 
The Bureau's suite of groundwater products is based on a common format and terminology for groundwater, resulting in a standardisation of groundwater data across Australia. For the first time, decision-makers have easy access to comprehensive, nationally consistent information on groundwater to support sustainable use of the groundwater resource across the nation (Figure 9. 8).

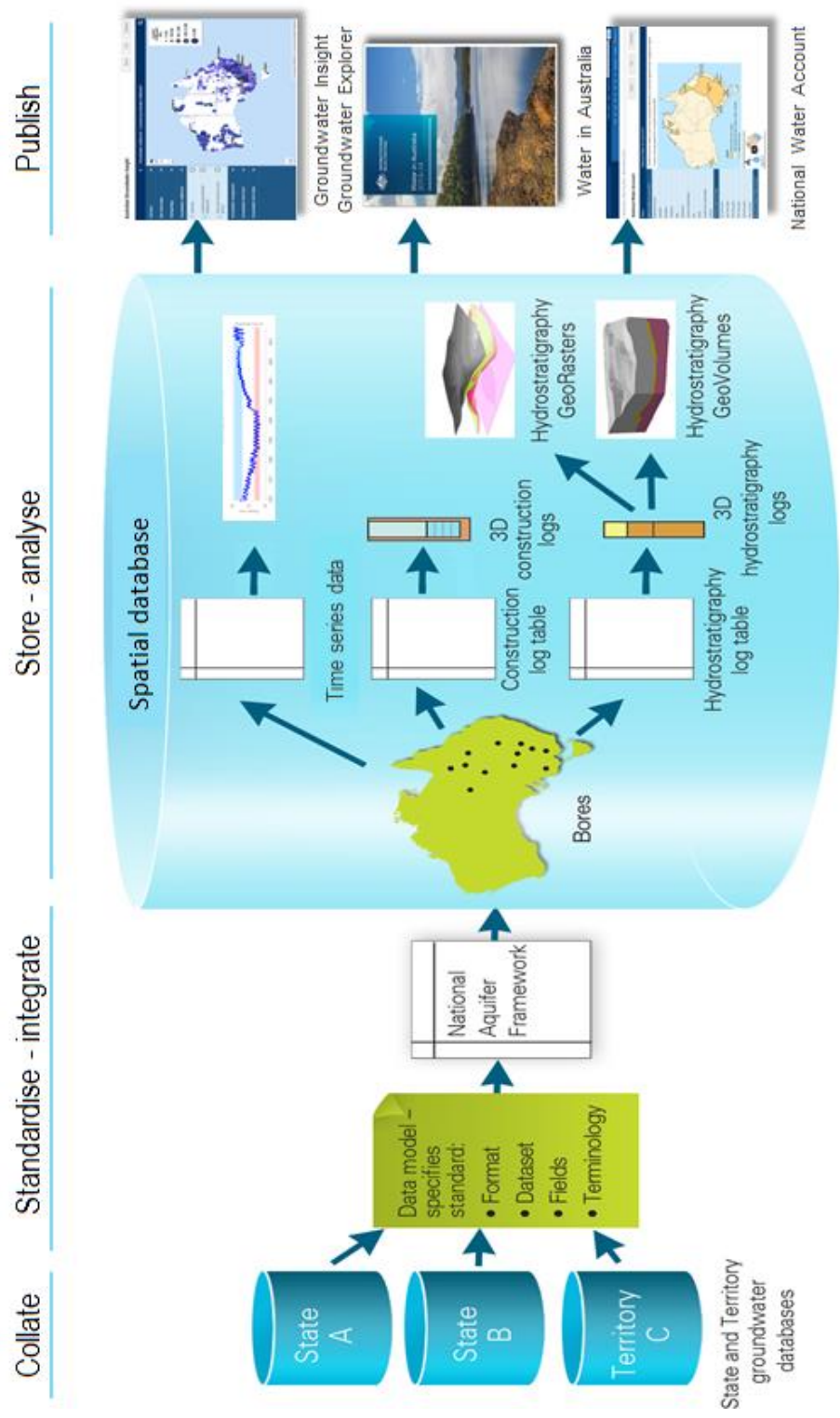


Figure 9. 8: Ingestion, standardisation, analysis and publication of groundwater information at the Bureau of Meteorology.

\section{Lessons learned, future challenges and oppor- tunities}

The history of GWIS development in France and Australia provides valuable lessons for countries currently engaging in developing a GWIS. This section summarises the differences and similarities in GWIS development in both France and Australia, including lessons learned and future developments.

\subsection{Comparative analysis of the historical development of GWIS in France and Australia}

In both countries, the need for groundwater information has emerged locally, leading local actors to design and implement independent GWIS. In France, diverse organizations have invested in GW monitoring, including Public Water Supply Utilities, various government ministries (agriculture, environmental, health affairs), and local government (county and regional councils). In Australia, data has historically been collected by state government and local water resource managers. Over time the focus of groundwater monitoring has varied, from resource exploitation, to dryland salinity management, to environmental protection and maintenance. Information produced by these early GWIS was not consistent in spatial coverage, monitoring frequency, measurement protocol, and data organisation and processing.

In both countries, the first challenge was to improve the geographical coverage of GWIS. Early systems were developing based on local initiatives, but public agencies had to step-in to fill gaps, using public funding. This mainly happened during the 1970's and 1980's. In France, the Water Agencies played a key role in developing GW monitoring network, sometimes relying on county and regional councils or Government agencies to establish and run the monitoring networks and information systems. The cost was paid by users through the water abstraction fees (see chapter 4 RINAUDO). Unlike France, where groundwater monitoring covers the entire nation, in Australia monitoring programs focus on areas of high groundwater use and good quality groundwater resources. Many aquifers, especially in remote and sparsely populated areas have little, or no, monitoring. Abstraction fees are collected in many management areas across Australia, however state governments also fund GWIS programs as part of their responsibilities to manage water resources for all users, including the environment.

Once the coverage of GWIS was satisfactory, the second challenge faced in both France and Australia was to standardise the existing heterogeneous GWIS. In France, the ministry established and imposed formats and protocol to all data producers. Conversely, the Australian Water Act of 2010 did not mandate any change in state GWIS, instead it implemented mandatory transfer formats, requiring water 
agencies to send data in these formats. The data was then standardised the once ingested into the national dataset.

The third challenge was to facilitate access to data collected and stored by many organisations. In France, this was facilitated by technological innovation in computer sciences such as, Web Services and APIs. By developing automated data exchange between the many organisations that hold groundwater data, nationally consistent GWIS were created by federating these existing systems into a coherent network. Conversely, in Australia each state and territory continues to maintain its own, independent GWIS. The vast majority of this data is published via the internet on data access portals specific to each state or territory (see example for Western Australia above). Nationally coherent groundwater datasets are produced by the $\mathrm{Bu}-$ reau of Meteorology who receive data from water agencies across the country and ingest into the national GWIS (see above, Groundwater Information Systems in Australia).

\subsection{Lessons learnt}

The development of independent GWIS in separate jurisdictions is most likely unavoidable. No single agency is able to develop a tool that meets the information requirements of all interested parties, e.g. resource managers, environmental protection agencies, abstraction compliance agents, among others. However, what can be learned from GWIS development in France and Australia is that the State should define, as early as possible, technical specifications so that the data and the independent GWIS are compatible. To reach this objective, a combination of economic incentives and regulation can be used. Also, significant resources should be devoted to the development of tools that can federate / integrate the data and make them available to users via the internet. This is because the cost of collecting this information is large and making these datasets publicly available is good practice and good use of public resources.

The responsibility for collecting, storing, and managing groundwater data is typically tied to a legislative requirement to manage groundwater resources. However, changes in groundwater systems typically occur at a much slower rate than changes in legislation and governments. As such, meaningful groundwater monitoring and data collection efforts occur across multiple iterations of governments, departments, and legislative changes. Both France and Australia have a long history of water data systems undergoing change as departments split and merge. Responsibility and funding can vary greatly over the monitoring history of a single resource. As such, when planning new information systems, it is important to plan for future management and maintenance of these systems. Are these systems extensible? Can extra functionality be added to meet new legislative requirements? For example, introduction of licensing information, where this was not previously enforced. Planning for a long-term system can greatly improve the longevity of the information system.

Effective data sharing across state borders has been, and remains, an issue within Australia. The Bureau of Meteorology has developed a standard to share water data, 
WDTF. The development of this standard has greatly increased the ability of the Bureau to manage the transfer and ingestion of large volumes of data. However, due to its complexity, and being dissimilar to existing formats, adoption of the standard was slow. Furthermore, the standard was developed to align with legislative requirements set out in the Water Regulations (2008). This did not include a holistic approach to groundwater data and does not cater for some commonly collected data, e.g. hydrogeochemistry. Where cross boarder data sharing is likely, adoption of such a standard is recommended, as it facilitates easy data sharing. However, to reduce the complexity and cost of implementation an existing standard can be adopted, for example GWML2 (Brodaric, 2016).

\subsection{Future developments}

Fifty years after the French and Australian GWIS started to be developed; managers have access to sophisticated technologies for data acquisition, transmission, and publication. These technologies are bringing about huge transformations in GWIS, including changes of infrastructure, operational process, volume and currency of data.

The availability of new technology is driving changes in monitoring devices and how they record and transmit data. More and more bores are being equipped with electronic monitoring devices as low powered IOT sensors, along with new transmission networks (GSM, low orbit satellite), reduce the cost and footprint of monitoring equipment. This is particularly attractive in Australia where monitoring networks are often spread over vast distances and cannot be monitored using existing communication networks.

Another transformation of GWIS may come from a greater demand of the civil to participate to the monitoring of the environment. Developments in communication technology, data processing and visualization will increasingly allow the general public to participate to the collection of data (crowed sourcing) and more generally to the production of knowledge (citizen science). While such data have a significant potential to create increase spatial coverage, in particular in remote regions, their integration with traditional monitoring network is challenging (Grieef and Hayashi 2007)

Publication of real-time groundwater data is a current, and ongoing, development in both France and Australia. Real-time data gives complete data transparency to managers, users, and the public. For example, the Méteau-Nappe application is currently being developed by Brgm to provide real time access to groundwater levels and to prediction of groundwater level evolution, updated at a monthly time step, based on realtime groundwater level data (Mougin et al, 2017). The state of New South Wales in Australia publishes extensive real-time groundwater level data. Their web portal (https://realtimedata.waternsw.com.au/) provides data for 488 bores, covering the major groundwater resources across the state.

In both France and Australia, developments in water information systems are now directed towards the development of APIs. In addition to data provisioning 
APIs, new programming interfaces are being developed to allow data processing and complex querying. This will eventually make it possible to call multiple remote environmental data sources and apply automated statistical processing. Spatially enabled APIs will also allow GIS users to make these aggregations based on spatial summaries and queries. These APIs will enable environmental management by making available not just raw data, but indicators that aggregate and draw inferences from multiple data sources.

\section{References}

Blum A., Winckel A., Laurent A. and Michon J. (2013) Les efforts de surveillance des eaux souterraines. ONEMA : Paris. 16 p. Accessible at http://www.eaufrance.fr/IMG/pdf/surveillanceeauxsouterraines 201301.pdf

Blum A., Lopez B., Guilbert M., Noël Y. and Chery L. (2010) Bilan national des efforts de surveillance des eaux souterraines à partir d'ADES. Indicateurs d'évaluation de l'état qualitatif et quantitatif des eaux souterraines: exemples de réalisations et recommandations. Rapport BRGM/RP-57943-FR. Onema :Paris. 166 p.

Alley WM, Evenson EJ, Barber NL, Bruce BW, Dennehy KF, Freeman MC, Freeman WO, Fischer JM, Hughes WB, Kennen JG, Kiang JE, Maloney KO, Musgrove MaryLynn, Ralston B, Tessler S, Verdin JP (2013) Progress toward establishing a national assessment of water availability and use. U.S. Geological Survey Circular 1384, 34 p, available at http://pubs.usgs.gov/circ/1384

Bartram, J. and Ballance, R. [Eds] (1996). Water Quality Monitoring-A Practical Guide to the Design and Implementation of Fresh Water Quality Studies and Monitoring Programmes. Chapman \& Hall, London.

Blake T., Cook M. (2006). Historical Overview: great artesian basin, Natural Resources Mines and Water, Queensland government.

BoM (2017), National Groundwater Information System, Data Product Specification, Bureau of Meteorology. ISBN 978-0642-706-430

Brodaric, B., Boisvert, E., Chery, L., Dahlhaus, P., Grellet, S., Kmoch, A., ... \& Wagner, B. (2018). Enabling global exchange of groundwater data: GroundWaterML2 (GWML2). Hydrogeology Journal, 26(3), 733-741.

Chapman, D. [Ed] (1996). Water Quality Assessments - A Guide to Use of Biota, Sediments and Water in Environmental Monitoring - Second Edition. UNESCO/WHO/UNEP. ISBN 0419215905 (HB) 0419216006 (PB)

BRGM, 2012 - Groundwater in France "Geoscience issues collection" brgm editions, ISSN 1775-7533, dépôt legal 2009, 2012 IAH French Chapter, BRGM, Ministry of Environment, Water Agencies, Afb. 
CLOETE N. A., MALEKIAN R., NAIR L. (2016). Design of Smart Sensors for Real-Time Water Quality Monitoring. IEEE Access. 4. 1-1. 10.1109/ACCESS.2016.2592958.

Dahlhaus, P., Murphy, A., MacLeod, A., Thompson, H., McKenna, K., \& Ollerenshaw, A. (2016). Making the invisible visible: the impact of federating groundwater data in Victoria, Australia. Journal of Hydroinformatics, 18(2), 238255.

DoM (1974), Department of Mines, South Australia, A Data Base Management System For The Storage and Retrieval of Geological Data. Rept.Bk.No. 74/76, G.S. No. 5395, D.M. No. 105/73, Eng.Geol. No. G34

Global Water Partnership Technical Advisory Committee (2000). Integrated Water Resources Management, Stockholm, Sweden. ISBN: 91-630-9229-8

Fitch, P., Brodaric, B., Stenson, M., \& Booth, N. (2016). Integrated Groundwater Data Management. In Integrated Groundwater Management (pp. 667-692). Springer, Cham

FedUni (2015), "Visualising Victoria's Groundwater." (internet data portal). Centre for eResearch and Digital Innovation, Federation University Australia, Mt Helen, Ballarat, Victoria. Retrieved 20/12/2017, from: http://www.vvg.org.au

Grieef, L. A., \& Hayashi, M. (2007). Establishing a rural groundwater monitoring network using existing wells: West Nose Creek pilot study, Alberta. Canadian Water Resources Journal, 32(4), 303-314.

Haley D., Beck A., Pollok A., Grant A., McKilliam R. (2017). Global Reach for the Internet of Things. 68th International Astronautical Congress (IAC), Adelaide, Australi. IAC-17-B2.4.3

Holliday, L., Marin, L. and Vaux, H. (2007). Sustainable management of groundwater in Mexico. Washington, D.C.: National Academies Press.

Horsburgh, J. S., Tarboton, D. G., Piasecki, M., Maidment, D. R., Zaslavsky, I., Valentine, D., \& Whitenack, T. (2009). An integrated system for publishing environmental observations data. Environmental Modelling \& Software, 24(8), 879-888.

Jousma G. [Ed] (2008). Guideline on: Groundwater monitoring for general reference purposes - Revision 2008. IGRAC, The Netherlands. Report nr. GP 2008-1

Klug, H. \& Kmoch, A. (2014). A SMART groundwater portal: An OGC web services orchestration framework for hydrology to improve data access and visualisation in New Zealand. Comput. Geosci. $69,78-86$.

Lee, J. Y. and Kwon, K. D. (2016). Current Status of Groundwater Monitoring Networks in Korea, Water, 8(4), 168; doi:10.3390/w8040168

Minsker, B. (2003). Long-Term Groundwater Monitoring-The State of the Art. In American Society of Civil Engineers. 
Mougin B., Nicolas J., Bessiere H., Vigier Y., Loigerot S. (2017). Vers une prévision en temps réel du niveau des nappes françaises? L'outil d'aide à la décision «MétéEau des nappes ». Revue Géologues n¹95.

NGC (1998), Review of Data Structures for Core Groundwater Data in Australia, NLP 97/7020 Project Report, National Groundwater Committee Working Group on National Groundwater Data Standards.

NSW (2012), NSW Strategic Investment Plan for Water Monitoring Systems, New South Wales Office of Water http://www.bom.gov.au/water/regulations/fundingProgram/document/NSW_Strategic_Investment_Plan.pdf, cited 6th March 2018

Porter, J. H., Hanson, P. C. \& Lin, C.-C. (2012). Staying afloat in the sensor deluge. Trends Ecol. Evol. 27 (2), 121-129

Taylor, C. J. and Alley, W. M. (2001). Ground-water level monitoring and the importance of long-term water-level data, U.S. Geological Survey Circular 1217, $68 \mathrm{p}$.

Tuinhof, Albert \& Foster, Stephen \& Kemper, Karin \& Garduno, Hector \& Nanni, Marcella. (2006). Groundwater Monitoring Requirements - for managing aquifer response and quality threats. 10.13140/RG.2.1.4530.9529.

UN-ECE Task Force on Groundwater Monitoring \& Assessment (2000). Guidelines on Monitoring and Assessment of-Transboundary Groundwater. RIZA Publication. Lelystad, The Netherlands. ISBN 9036953154

Vaessen, V., \& Brentführer, R. (2014). Integration of groundwater management: into transboundary basin organizations in Africa - a Training Manual by AGW-Net, BGR, IWMI, CapNet, ANBO, \& IGRAC

Walker, G., Taylor, P., Cox, S., \& Sheahan, P. (2009). Water Data Transfer Format (WDTF): Guiding principles, technical challenges and the future. In Proc. 18th World IMACS Congress and MODSIM09 Int. Congress on Modelling and Simulation (pp. 4381-4387).

Water Act (2007), Act No. 137, C2007A00137, retrieved from https://www.legislation.gov.au/Series/C2007A00137, 9th March 2018

Water Regulations (2008), F2008L02170 SLI 2008 No. 106, retrieved from https://www.legislation.gov.au/Series/F2008L02170/, 9th March 2018

World Meteorological Organization (WMO) (2008) Guide to hydrological practices. WMO, Geneva, pp 